\title{
The Bethel AME Church Archive: Partners and Participants
}

\author{
Andrea Copeland
}

Community archives have proven vital for giving a voice to underrepresented groups. Formal institutional archives have traditionally represented the dominant narrative in society and continue to do so, excluding access to cultural records and artifacts of underrepresented groups. Well-funded cultural heritage institutions have the infrastructures of support to provide long-term preservation and access on a global scale. Connecting community archives to this infrastructure of support is the overarching goal of my research (Copeland, 2015). How to make that connection in a way that respects the community and the purpose of the archive remains to be determined.

This chapter will detail my journey with one particular community and its archive.

Bethel is the oldest African American church in the city of Indianapolis, and was once a vital part of a thriving African American community in the heart of the Indiana Avenue Jazz District. The Church was founded in Indianapolis in 1836, and its archive documents a shared heritage and a living community. Over its 180 years of existence, the Bethel AME Church has played a vital role in the Underground Railroad, the founding of the National Association for the Advancement of Colored People (NAACP) in Indiana, the founding of the first formal School for Black Children in Indianapolis, and the development of the African Methodist Episcopal Church in the United States. In the 1960s and the 1970s, the development of the Federal interstate highway system and of Indiana University Purdue University Indianapolis (IUPUI) displaced many members of the community over the course of just a few decades. Where the church was once surrounded by the homes and businesses of its members, high-end condominiums now encroach on the tiny parcel upon which the crumbling brick building stands and IUPUI's five-story School of Informatics and Computing, where I work, looms across the street.

For the past two years, I've worked closely with Olivia McGee-Lockhart, the Bethel AME Church of Indianapolis' Keeper of History, church archivist and historian. Indianapolis is the state capitol of Indiana in the United States. Our common goal is to preserve and make accessible the church's archive dating back to the 1850s. The oldest items in the archive include hand written journals, letters, and other evidence that the church was a station on the underground railroad, a network of individuals and organizations helping slaves escape from the south (National Parks Service, n.d.). This archive came to my attention only because one of our School's alumni, Rodney Freeman, was a member of the church and sought my help. Unfortunately, many community archives are similarly discovered by happenstance as there are no connections to bridge marginalized groups to formal support structures. To lessen the role of chance in whose history is preserved, methods for creating connections between resource-rich archival institutions and history's underrepresented groups are desperately needed if a more inclusive historical representation is to be realized.

Over the years, Bethel's membership has dwindled, and the majority of its parishioners are now elderly. These church members, in particular Ms. McGee-Lockhart, contribute to the contextual

This is the author's manuscript of the chapter published in final edited form as:

Copeland, A. The Bethel AME Church Archive: Partners and participants. In Roued-Cunliffe, H., \& Copeland, A. (2017). Participatory Heritage. London: Facet Publishing. 
narrative that supports the documentary evidence. Like many others, this community archive has survived because of the dedication of one or two individuals who understand the value of the past. Ms. McGee-Lockhart has spent her life caring for and researching the church archive. As a life-long member, she learned a great deal from the first Keeper of History, Ms. Frances Connecticut Stout, who started caring for the archive in the early 1940s. She inherited the role from Ms. Stout 12 years ago. As the church parish continues to dwindle, it is increasingly unlikely that someone will be there to inherent the role.

In an ideal world, the Bethel AME Church archive would remain in the church and yet somehow be preserved and made globally accessible. This would keep the archive in the community and the community in the archive.

Historically, underrepresented communities have created archives for use by their members to advocate for their current and historical representation in society. However, community archives face many challenges, such as lack of expertise in the areas of preservation as well as technical and financial sustainability, because they prioritize the use of records to support current community information needs rather than long-term preservation.

Given the current circumstances in which the church building is about to be sold for redevelopment, it is not possible to keep the archive in the church, preserve it and create access to it. If this were possible, would it be the best approach to promoting intellectual access to the documents and contributing to the study and understanding of African American history in Indianapolis, the state of Indiana and in the US? Probably not. The church is not in the position to organize, preserve, and provide access to historical information.

This led me to a quandary: what local heritage institutions would be best to partner with for preserving and providing access to both the physical and digital archive, and where would the physical archive of the Bethel AME Church reside after digitization?

For our first attempt at finding funds to support the work of organizing the physical collection and digitizing the documents, we submitted a proposal to the National Archive and Records Administration for their Literacy and Engagement with Historical Records Grant initiative.

For this initial effort, we struggled to find local partners. In part because this particular archive is rather large (over 180 years in the making) and not processed - a daunting archival task. Also, the local heritage institutions are currently sorting out among themselves who should or could engage with and preserve whose history. Ultimately, Indiana Historical Society (HIS), the IUPUI University Library and the Indianapolis Public Library should interest in accepting the challenge. IHS, founded in 1830, is heavily endowed and utilized by scholars and residents alike. The IUPUI campus has a strong commitment to community engagement, and as such, the University Library has digitized several local heritage collections of relevance. Lastly, the Indianapolis Public Library has digitized local collections representing the history of the city. Among these institutions there is the potential for overlap of mission and collection development policies. Also, each institution has competing and complementary technical infrastructures and competencies. How these institutions will work together to preserve the city's history is still being worked out. I feel that this project could provide some insight into this evolving situation.

Given the deadline of the grant and the mission differentiation issues mentioned above, we initially decided to work with Notre Dame's university library in South Bend, Indiana (four hours' drive from Indianapolis) and to keep the physical collection at the church. A local advisory board was formed to direct the processing and digitization of the collection. 
This grant initiative specified community engagement technologies be a part of making the archive available online. We were excited about this, as we would like to find ways to keep the community engaged with and contributing to the archive once it is moved outside of the physical confines of the church. However, the reviewers determined that our plan for online engagement was not an ideal fit with Bethel's predominantly elderly parish (Personal Communication, NARA Grant Reviewer, 2015):

"The real value to this project comes in the creation of the additional web applications to Omeka to allow for and encourage community engagement. I think this is a very valuable addition to the open source software but I am curious if the project planners and the advisory board has considered how they will reach their intended audience that comes from an age group that is not necessarily comfortable in an online environment and may not have the willingness to engage in oral histories and discussions online where there may be sensitivities to privacy issues that are not as present in the younger generations."

After a second round of reviews, we were not successful in getting funded and were advised to take the archive to IHS when the church was finished with it, thereby taking the community out of the archive as well as the archive out of the community. (In our response, to the first round of reviews, IHS agreed to provide a home for the physical collection after the digitization was completed.)

Meanwhile, the church was facing a larger problem than the preservation of the archive. The church building that had served the community well for over a 150 years was now in desperate need of repair and the church was faced with having to sell the building in order to survive. This was devastating news. Bethel is one of three remaining buildings left representing the AfricanAmerican heritage in this historic part of downtown Indianapolis, and the oldest building on the city's canal.

The combined efforts of economic development and city planning have, intentionally or unintentionally, erased the African-American footprint from downtown Indianapolis. Indiana Avenue and the Central Canal are desirable locations for businesses and the city has invested considerable resources in the area to make it vital. Years ago, African Americans invested considerable resources in exactly the same way. Unlike other cities with significant arts districts and histories, Indianapolis chose not to preserve its heritage if favor of "progress." Cities such as New Orleans and Memphis respected their African American cultural heritage and clearly show the benefits of having done so. As a result, the Indianapolis downtown near the IUPUI campus feels like a space rather than a place, and Indiana's African Americans are being denied part of their cultural heritage.

In its heyday, Indiana Avenue was known as The Jazz District. Along with the church, the Madame Walker Theatre still stands and features a functioning theater venue and a small museum collection. Crispus Attucks was the only all-black high school in Indianapolis from 1927 to 1967. The school houses a four gallery history museum on the African/African American Experience, but its existence is being threatened by the need for a girls' athletic facility. In addition to these buildings, the Ransom Park neighborhood is the only fragment of residential area that remains, surrounded by apartment complexes built to provide homes to IUPUI students (Briggs, 2015).

Through constantly sharing the plight of the church with anyone who would listen, I found someone in the IUPUI administration, Khaula Murtadha, to help connect the church with local 
officials and the media. Through her connections, Ms. McGee-Lockhart and I were featured on the Amos Brown radio show to promote a walk on the Central Canal to gather support for the church (Amos Podcast, 2015). The city's newspaper, the Indianapolis Star, sent a reporter to the walk to run an article on the church's plight (Lewis, 2015). Before long, the pastor, Louis Parham, and I were appearing on the Fox 59 evening news together (2015) and the editor-inchief of the Indianapolis Monthly was featuring the disappearance of buildings and organizations vital to the preservation of the city's history (Heckert, 2016).

Thankfully, the local press helped re-engage the local heritage institutions, and we were once again trying to figure out how best to handle the archive. Rather than starting from the perspective of the institutions, I suggested we focus on the potential users of the archive, which would most likely be researchers or members of the church. While the IUPUI library has an impressive digitization program, it cannot store physical collections once they have been scanned. We brought everyone together to determine the best way forward and it was decided that IHS was the best place for the physical documents, given the expertise and facilities located there.

For months now, a project team has been working on how to best to preserve the physical items and provide access to a digitized collection of the physical records. This team includes Olivia McGee-Lockhart, myself, Kisha Tandy from the Indiana State Museum, Jenny Johnson from the IUPUI University Library, and Wilma Moore and Susan Sutton from the Indiana Historical Society.

Given the social, historical and technical complexities of the project, expertise in many disciplines is needed, such as information technology, archival science, metadata protocols, and knowledge of local, church, and African American history.

The team was successful in securing a grant from the Indiana State Library to provide for the digitization of these records. Ms. McGee-Lockhart and Kisha Tandy worked together for several months to organize the collection at the broadest level, and created finding aids in order that the collection could be moved to IHS for processing by Wilma Moore.

Once the collection is processed, it will be temporarily moved to the IUPUI library for digitization and the attribution of basic metadata. Public access to the digitized records will be made available through the IHS as the society uses the funds from the sale of high resolution digital copies for financial support. The value of charging for access is debatable especially when you consider the limitations placed on reuse that could promote IHS to a broader audience (Tanner, 2004). The IUPUI library does not charge to access high resolution files. There was some tension among team members regarding charging for said files, given that public funds will be used to digitize the files. However, IHS was not interested in storing the physical archive without also having the benefits of the digitized records. The IUPUI library always keeps a high resolution file of the documents which they scan for other institutions. A copy of the digitized archive will be available to build community engagement projects around the Bethel story. At this point, we also agreed that a hard drive with all of the scans would also be given to the church. This comprise works to a certain extent. However, as Roued-Cunliffe points out in the chapter on open-data, these types of institutional restrictions inhibit the use of these resources in new ways that ultimately increase information discovery and knowledge creation,

The Bethel archive contains mostly records contributed by congregants about the history of the African American community in Indianapolis as well as the church. IHS has other collections of 
local significance, and the Bethel collection will add to this resource for scholars doing research about the area. As IHS is located one block from the church, parishioners would have relatively easy access to their collection - the next best thing to having the archive housed in the church. However, soon the Bethel congregation will be relocating to the suburbs of Indianapolis after calling the historic downtown building home for 150 years.

The African-American footprint continues to be slowly erased from the downtown Indianapolis fabric without regard for preservation of cultural heritage. A growing number of individuals, scholars, heritage professionals, and journalists are not only trying to preserve what little is left, but also find ways to bring the culture that once was back to the area. The Bethel archive is an important part of this effort. It provides a wealth of evidence that the church is a vital part of Indiana history, and helps illustrate the history of Indiana Avenue. Had it not been for the careful conservation of the Bethel AME archive by church members, the history of the church and its role in greater African American history would have been lost. To date, the archive has played a significant role in having the church building designated a national and state landmark, and a station on the Underground Railroad (Indiana Historical Bureau, n.d.).

When Ms. Stout turned over the responsibilities of keeping the church's history to Ms. McGeeLockhart in 2004, she instructed Ms. McGee-Lockhart to never let the archive leave the building and to trust no one outside of the congregation with it. At that time, she never envisioned a day when the church land and building would be sold and the congregation relocated outside of the downtown area (Lewis, 2016). Nor did she anticipate a day when records could be copied and distributed around the world through networked computing.

After careful consideration and through the carefully built trust in the individuals representing the IUPUI Library, the Indiana State Museum and IHS, Ms. McGee-Lockhart, Bethel's designated Keeper of History, has agreed to release the archive. While it is not exactly a happy occasion for her, liberating the archive from the building will enable the history of the church to be shared.

Doing so will allow untold others to participate and benefit from the church's heritage.

Given the current situation with the church property being sold and rezoned for commerce, preserving the church building is important to Indiana Landmarks and to many in the community. At this moment, the fate of the building remains unknown. Unfortunately, the contract between the church and the developer only specifies that the main façade and the bell tower be preserved. (A city planning hearing is scheduled for July 28, 2016 which will determine how much of the building will preserved.)

The National Trust for Historic Preservation's (NTHP) This.Place.Matters. (n.d.) campaign has drawn attention to heritage sites in need of preservation. The NTHP website provides a toolkit designed to help individuals tell stories about the places they think should be preserved. NTHP encourages participants to share their stories through social media: Twitter, Facebook, and Pinterest. Twitter is heavily used to document places that matter; for example, the aforementioned Ransom Place neighborhood adjacent to Indiana Avenue joined this campaign with the hashtag \#RansomPlaceMatters. The hashtag \#BethellndyMatters has been created to draw attention to the preservation needs of the church building.

On July 24, 2016, a community event will be held at the church. At this event, a team of volunteers will conduct oral histories with the remaining congregants to capture their feelings about the sale of the building and the departure of the congregation from downtown. Additionally, community members will be invited to reflect on their feelings about the inevitable 
diminishing of the African American heritage footprint. Participants will be invited to be photographed with old photographs of church events. They will be asked to reflect on what it means to bear witness to a time and place that will only exist in documents in the near future. Community contributions will be recorded and connected to the archive once it is digitized.

Continued community engagement with the digitized archive will serve to keep the African American narrative as part of the fabric of the city's history. Hopefully, it will also serve as a reminder that it is important to preserve and acknowledge the accomplishments of those that have gone before us for those who have yet to come. We owe it to past and future generations to facilitate personal connections to history. We have to do a better job of showing that history matters. We fail as a profession, a community, a city, and as a nation when history is not respected and preserved in favor of "progress" and profit.

Amos Podcast. (2015, August 20). Is Indy's oldest black church in danger? http://praiseindy.hellobeautiful.com/2066304/amos-podcastaug-20-is-indys-oldest-black-churchin-danger-in-peril-2-black-lawmakers-pushing-for-police-bodycams-dashcams/

Copeland, A. (2015). Public Library: A place for the digital community archive. Preservation, Digital Technology \& Culture, 44(1), 12-21. https://scholarworks.iupui.edu/handle/1805/6117

Fox 59 News. (2015, September 9). Developers looking to purchase historic Indianapolis church, community fighting to save it. http://fox59.com/2015/09/09/developers-looking-to-purchase-historicindianapolis-church-community-fighting-to-save-it/

Heckert, A. (2016, May 3). The changing face of Indiana

Avenue. http://www.indianapolismonthly.com/news-opinion/changing-face-indiana-avenue/

Indiana Historical Bureau. (n.d.)_http://www.in.gov/history/markers/Bethel.htm

Lewis, O. (2015, August 22). Bethel AME fights to keep legacy alive. Indy Star.

http://www.indystar.com/story/news/2015/08/22/bethel-ame-fights-keep-legacy-alive/32209385/

Lewis, O. (2016). Indy's oldest African-American church sold for hotel space. Indy Star.

http://www.indystar.com/story/news/2016/04/08/indys-oldest-african-american-church-sold-hotelspace/82765744/

National Parks Service. (n.d.) Aboard the Underground Railroad: Bethel AME Church. https://www.nps.gov/nr/travel/underground/in1.htm

Personal Communication. NARA Grant Reviewer.

Briggs, J. (2015, December 23). Ransom Place residents say discrimination may have led to housing project approval. http://www.indystar.com/story/money/2015/12/23/ransom-place-residents-saydiscrimination-may-have-led-housing-project-approval/77764910/

Tanner, S. (2004). Reproduction charging models \& rights policy for digital images in American art museums: A Mellon Foundation Study. http://www.kdcs.kcl.ac.uk/fileadmin/documents/USMuseum SimonTanner.pdf

This.Place.Matters. (n.d). https://savingplaces.org/this-place-matters\#.V04FDuZfX-U 